\section{Penetration efficiency of small sized conical shaped charges in steel targets}

The Mining-Geology-Petroleum Engineering Bulletin UDC: 662.215 .2

DOI: $10.17794 / \operatorname{rgn} .2019 .2 .3$

Original scientific paper

Lorand Kugyela'

${ }^{I}$ TÜV Rheinland InterCert Ltd. Notified Body for Explosives, 1132 Budapest Vaci ut 48/A-B

\begin{abstract}
This paper describes research on the testing of small sized point focal shaped charges. They were manufactured from composite-B, Semtex and pressed RDX, binary explosives, and emulsions. As the liner and the whole structure of the charges were identical, the mild steel penetration test was a clear method for comparing and quantifying their performance. The target setup was also standardized with different steel discs. During testing, it was realized that this was a practical development tool, to find the proper mixture for binary explosives. Since most of the shaped charge literature related to their evaluation was rather detailed theoretical work, the goal was to develop a simple, yet productive performance testing method that is more suited to practical field works.
\end{abstract}

Keywords:

melt cast; shaped charge; penetration test; binary explosives

\section{Introduction}

In the past decade, an enormous amount of scientific research has been focused on the shaped charge phenomenon (Walters, Zukas, 1989). One common approach arises generally in them, the authors' own way of thinking, to underpin the related existing thermodynamics and physics from their own point of view (Brown et al., 1993). The idea to use the shaped charge mechanism (Kamarudin et al., 2016) for testing explosives is not new. The general question raised regarding high explosives is whether or not they were suitable for different shaped charge application.

Conventionally, two categories can be drawn up regarding an increase or modification of the penetration abilities of a shaped charge. The first one is the adjustment of the structural appearance, like the liner material, the cone angle, the standoff distance, the wave shaping, the initiation, the confinement, etc. The second strictly relates to the explosives, like the explosive properties, the loading density, etc. By changing any of the abovementioned criteria, significant changes may appear (Bohanek et al., 2012; 2014). The procedure outlined in this paper was to manufacture a standardized shaped charge structure, with which it is possible to measure different explosive compositions' penetration performance and use this approach as a brisance predicting method. For the jet formation, some explosive properties have great importance such as the critical diameter, the

Corresponding author: Lorand Kugyela

lorand.kugyela@hu.tuv.com detonation velocity, and density. These properties together are crucial for an appropriately shaped charge.

Before the test, candidates were needed to establish a fundament for the investigation. For this purpose, two materials were chosen, one was a semi-finished product for a high penetration capability $40 \mathrm{~mm}$ grenade, with a pressed shaped charge, and another one was a commonly available plastic explosive. The focus of the trials was to build up a reproducible setup and then collect data for the further development of binary explosives and other explosive mixtures' penetration abilities. The approaches of these tests are similar to those in the STANAG 4526 (Bakera et al., 2013).

\section{Set-up of the shaped charge assembly}

The copper cone liners had a $60^{\circ}$ cone angle, and a 1.5 $\mathrm{mm}$ thickness. Their average weight was $13 \mathrm{~g}$. With some technical help from a turner company, a liner holder mounting was manufactured that served more purposes. Most importantly, it centralized a liner in an axisymmetric position, acted as a standoff and a reversed cone air cavity. The tubing was an aluminium pipe that could be cut to a predefined length. It holds the liner mounting at the bottom, and the detonator centralizer disc at the top. Figure 1 shows the liner mounting crosssection. Figure 2 shows the shaped charge components.

The target assembly is a centralizing and clamping unit that holds the target mild steel discs tightly together and holds the shaped charge in the proper place (see Figure 3). The two, separate central aligned fixtures hold the 


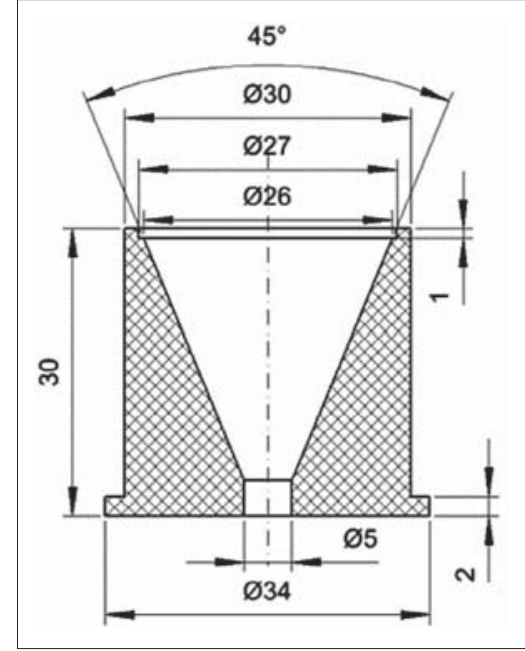

Figure 1: Liner mounting cross-section

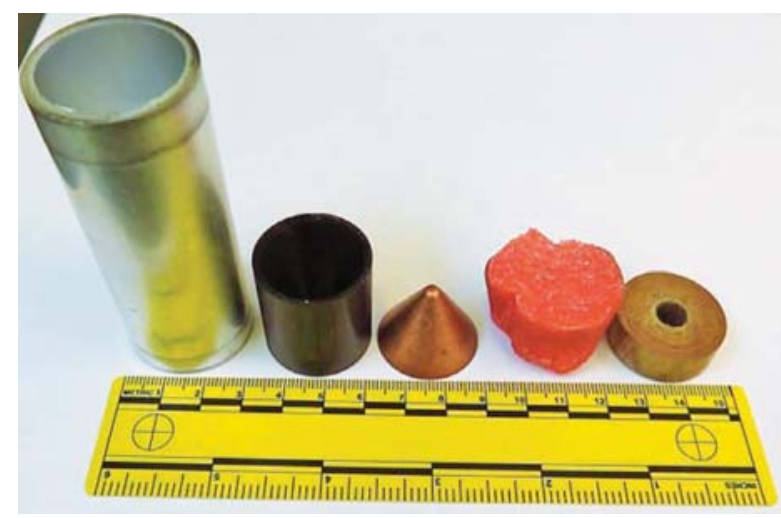

Figure 2: Shaped charge contents

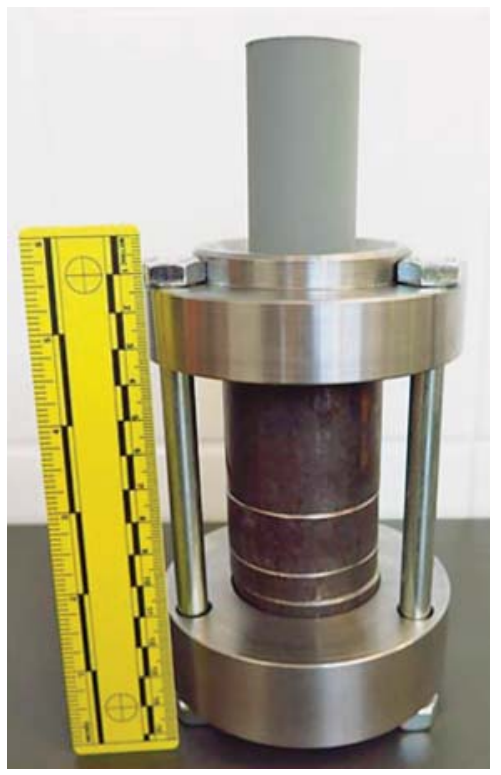

Figure 3: Target assembly with a shaped charge on the top target assembly with three screws and a small ditch inside, while they pull and lock the discs together. This structure offers a fast, convenient way of testing as the settings can be varied quickly as a different disc sequence can be adjusted. For example, if we predict that the penetration will be bigger than $50 \mathrm{~mm}$, first we place the $50 \mathrm{~mm}$ disc then $10 \mathrm{~mm}$ or $20 \mathrm{~mm}$. In case of smaller penetration, thinner discs can be placed under the charge. This setup eliminates human-borne positioning errors. Due to the standoff distance, the explosion does not damage the head part and up to now, the device withstands several dozens of blasts.

\subsection{Explosives for shaped charges}

Four different types of explosives were used to validate the idea. Plastic explosives, such as Semtex 1A and Semtex PLHX30 are commonly available and exceptionally suitable for this task. Pressed explosives as mentioned in the introduction for this charge is a RDX containing a semi-finished product with high dimensional accuracy, see Figure 4. The binary explosive mixture was a classic nitro-paraffin / oxidizer mixture with and without atomized aluminium. The melt cast material was Comp-B with a ratio of: $60 \%$ RDX $40 \%$ by mass.

Manufacturing of the cast explosive itself was a challenging method, as the solidification, and the heat conduction problems of the small sizes and quantities $(\sim 22$ g-46 g) of materials can cause more significant discrepancies than in productions of several kilograms. The shrinkage percentage of TNT containing melt cast explosives during the solidification process can be up to $10-11 \%$. If we convert this ratio to small volumes, the non-homogenous part of the explosive positioned more closely to the liner and the initiation point, this phenomenon can result in uneven jet formation. In case of larger size melt cast explosives, this unevenness is counterpoised by the bigger mass and longer distance between the initiation point and the liner.

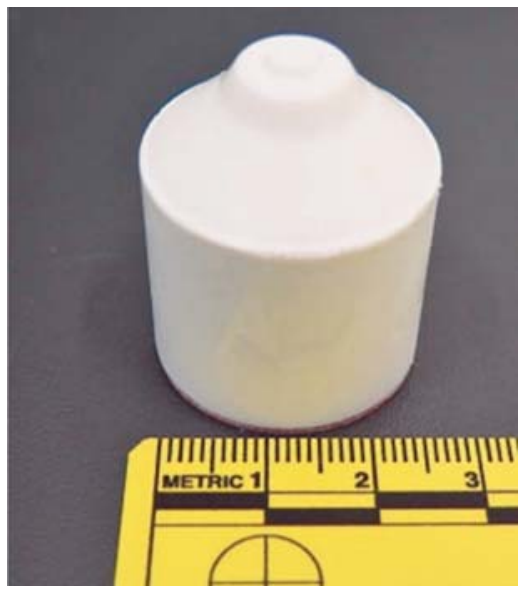

Figure 4: RDX Shaped Charge 


\section{Penetration tests in mild steel targets}

During the experiment, differently shaped charges were tested. Table 1 describes their type, weight and other necessary remarks.

Table 1: Explosives used in the test

\begin{tabular}{|l|c|c|}
\hline \multirow{2}{*}{ Explosive } & Weight & \multirow{2}{*}{ Remark } \\
\cline { 2 - 2 } & (g) & without waveshaper \\
\hline Semtex 1A & 25 & with waveshaper \\
\hline Semtex 1A & 25 & $8 \%$ Al content \\
\hline Semtex PLHX 30 & 25 & pressed \\
\hline RDX & 14,3 & cast \\
\hline Comp-B & 25,1 & cast \\
\hline Comp-B & 30,8 & cast \\
\hline Comp-B & 46,1 & cast \\
\hline Comp-B & 22,6 & $2.5 \%$ Al \\
\hline AnNmA1* & 50 & $2.5 \%$ Al \\
\hline AnNmAl & 25 & without Al \\
\hline AnNm & 50 & without Al \\
\hline AnNm & 25 & \\
\hline
\end{tabular}

* AnNmAl: Ammonium-nitrate, nitromethane, aluminium mixture
First, the plastic explosives were tested. During the experiments, the collar diameter of the hole and the depth of penetration were measured.

In the Semtex 1A sample (see Figure 5), the diameter decreased by a $2 \mathrm{~mm}$ average in case of the waveshaper but the penetration increased from $46 \mathrm{~mm}$ to $51.6 \mathrm{~mm}$. For the Semtex PLHX30, the hole diameter was $9.1 \mathrm{~mm}$ and the length $51.5 \mathrm{~mm}$, (see Figure 6). As the plastic explosives were exceptionally suitable for high performance shaped charges, the results of each case showed symmetry and repeatability.

The RDX pressed charge (see Figure 7) showed some inconsistency which could be attributed to the pressing procedure. From each of the 3 blasts, some amount of copper splatter remained on the surface of the discs. The average diameter at the collar was $7.3 \mathrm{~mm}$, and the length was $51 \mathrm{~mm}$.

Manufacturing of the melt cast composition in such small charges proved to be challenging. Melting the TNT and adding RDX took place in a Teflon coated pan with steam heating at $90^{\circ} \mathrm{C}-91^{\circ} \mathrm{C}$. Meanwhile, the shaped charge assembly was heated in a steam bath to avoid instant solidification during the filling process. A vibration motor was built into the mounting of the shaped charge, in order to eliminate the shrinking issues during the cooling phase. In theory, this seemed obvious, but in practice, it was different. The vibration alone did

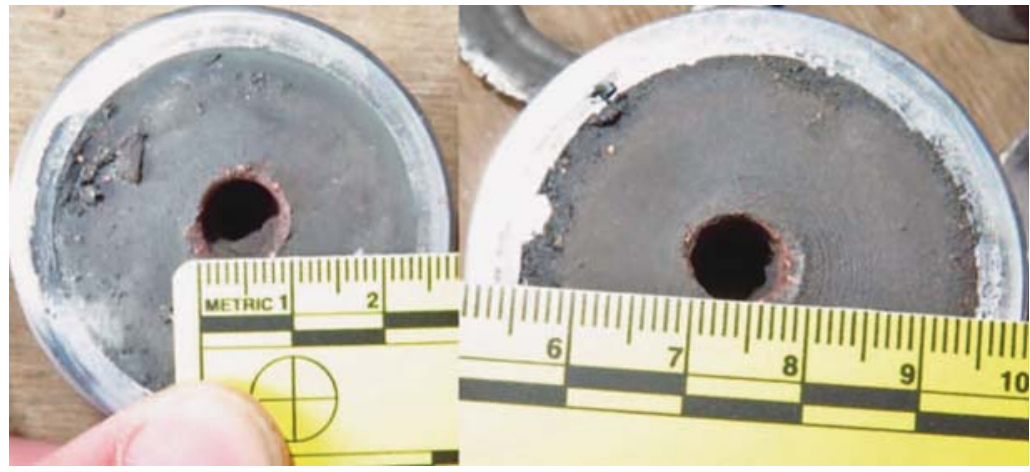

Figure 5: Result for Semtex 1A with (right), and without a waveshaper (left)

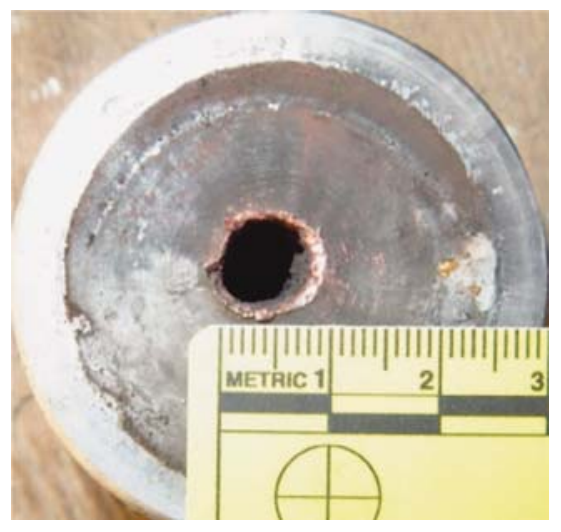

Figure 6: Result for Semtex PLHX 30 not solve the solidification. The fill-up was carried out in multiple steps. Between each step, the floating "plate" shattered, then the next portion was poured immediately. With this procedure, the reducing volume filled up with molten material instead of an air gap. Without continuous stirring, the $4 \%$ wax content of the RDX accumulated at the top of the melted explosive mixture. Since around 5 grams of RDX dissolved in 100g TNT (TM 9-1300-214 Military Explosives), regular agitation was mandatory to avoid layering of the explosives. Without this action when the charged body was filled, different density and concentration explosive sections would build up which could have raised the sensitivity of the ignition. The RDX eutectic would settle around the liner 


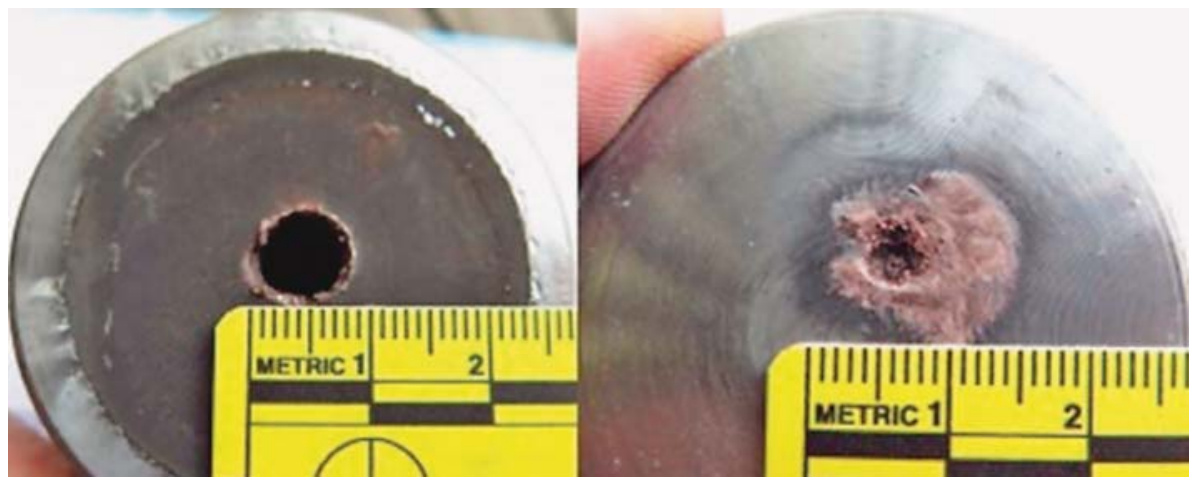

Figure 7: Pressed RDX charge entry (left), and the jet on the second disc (right)

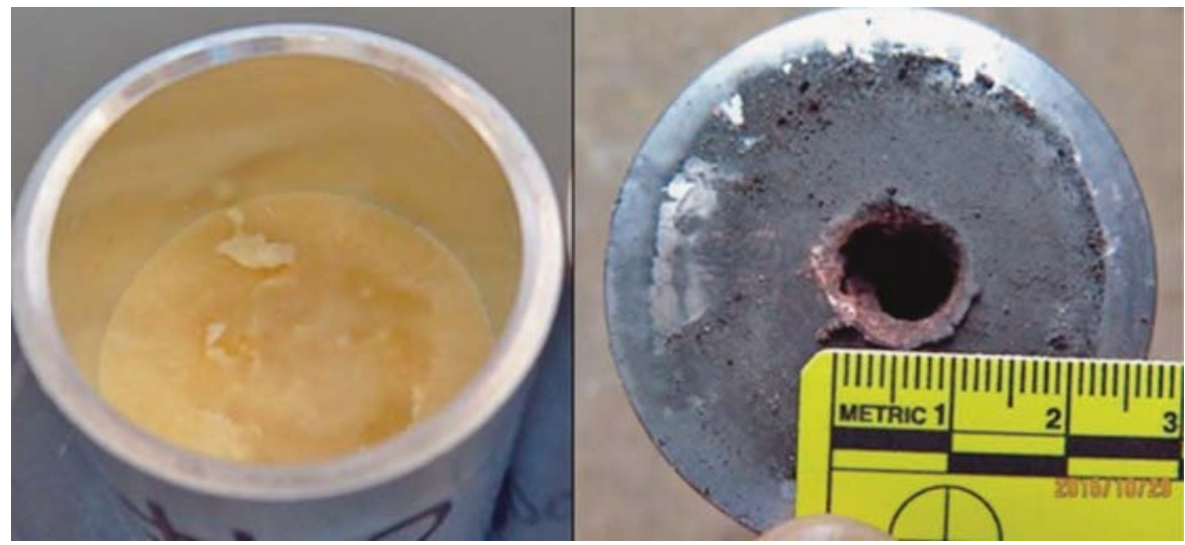

Figure 8: Result of 25.1 $\mathrm{g}$ composite-B

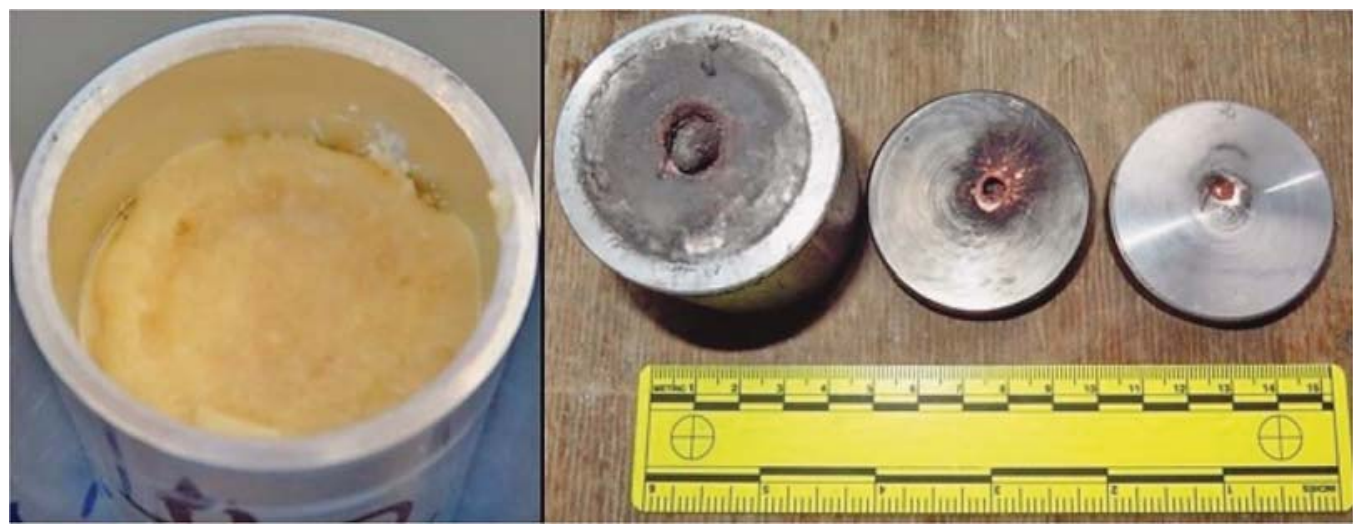

Figure 9: Result of $30.8 \mathrm{~g}$ composite-B

and in the top segment, a TNT rich layer was built up with a wax layer on the surface. For the performance test, four composite-B charges were made. The weights of explosive were from $22.6 \mathrm{~g}$ to $46.1 \mathrm{~g}$

In Figure 8, it can be seen that this amount of composition barely covered the liner. The diameter was $9.4 \mathrm{~mm}$ and the length was $32.3 \mathrm{~mm}$.

Figure 9 shows that even though the slug remained at the collar point at the disc, the penetration was almost double the previous one. The diameter was $10 \mathrm{~mm}$ and the length was $61.5 \mathrm{~mm}$.

This shaped charge contained the largest amount of cast explosive and had a sizable penetration length of 71 $\mathrm{mm}$ and a diameter of $11.2 \mathrm{~mm}$. Figure $\mathbf{1 0}$ shows the penetration of this charge on the $50 \mathrm{~mm}-10 \mathrm{~mm}-10 \mathrm{~mm}$ $-10 \mathrm{~mm}$ mild steel discs.

In Figure 11, the effect of the asymmetrical jet formation can be seen. Presumably, the tail part (slug) came 


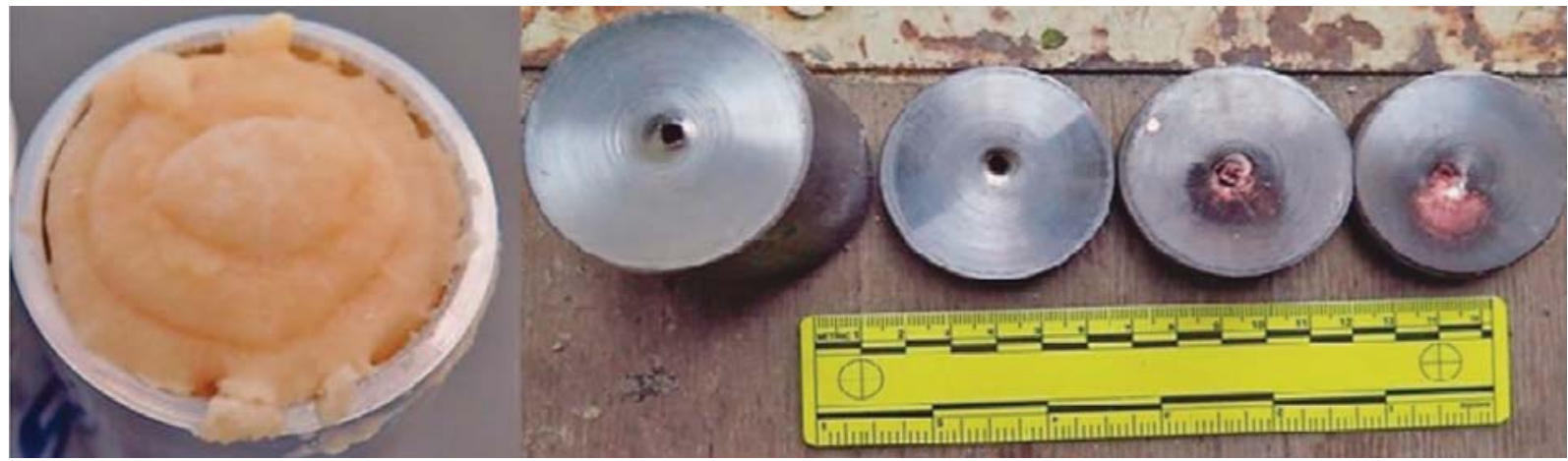

Figure 1o: Result of $46.1 \mathrm{~g}$ composite-B

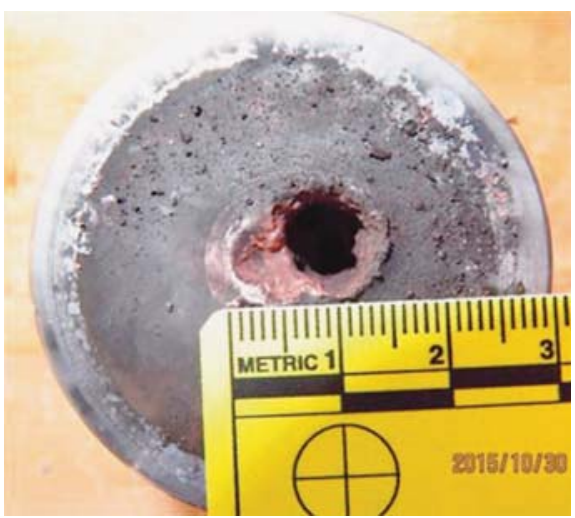

Figure 11: Result of $22.6 \mathrm{~g}$ composite-B

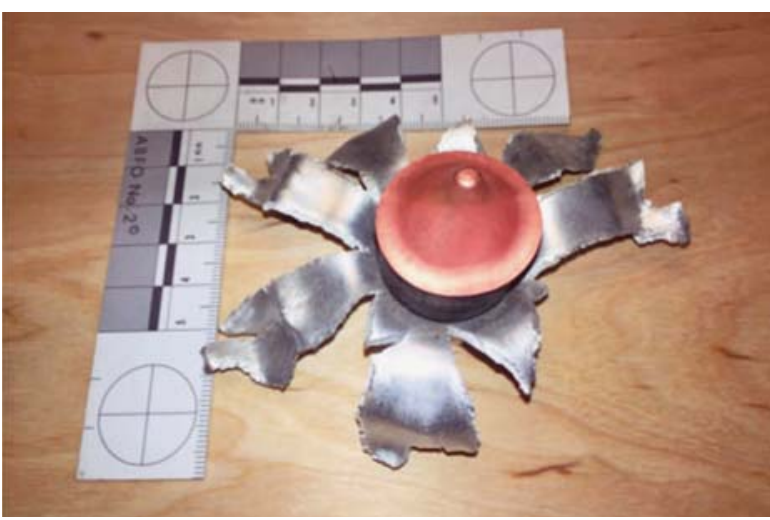

Figure 12: Result of $22.6 \mathrm{~g}$ composite-B

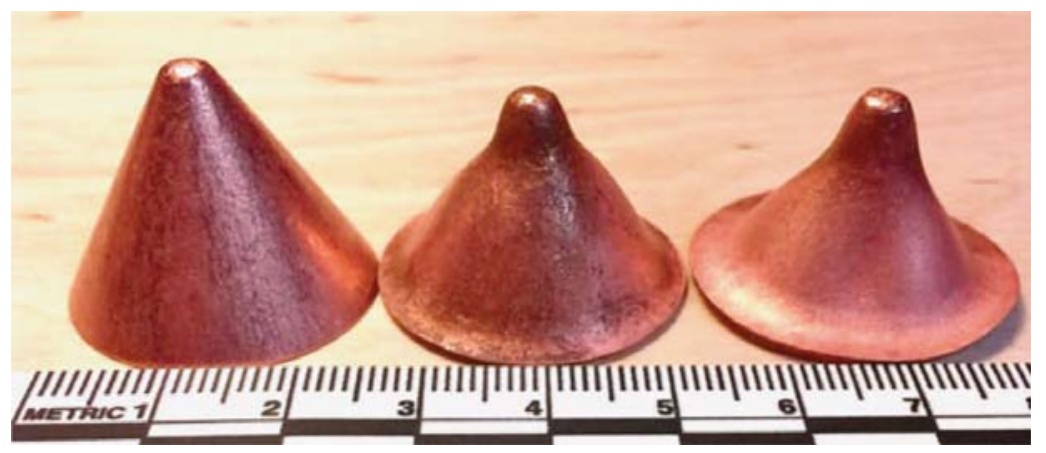

Figure 13: Intact (left) and deformed liners due to partial detonation (middle, right)

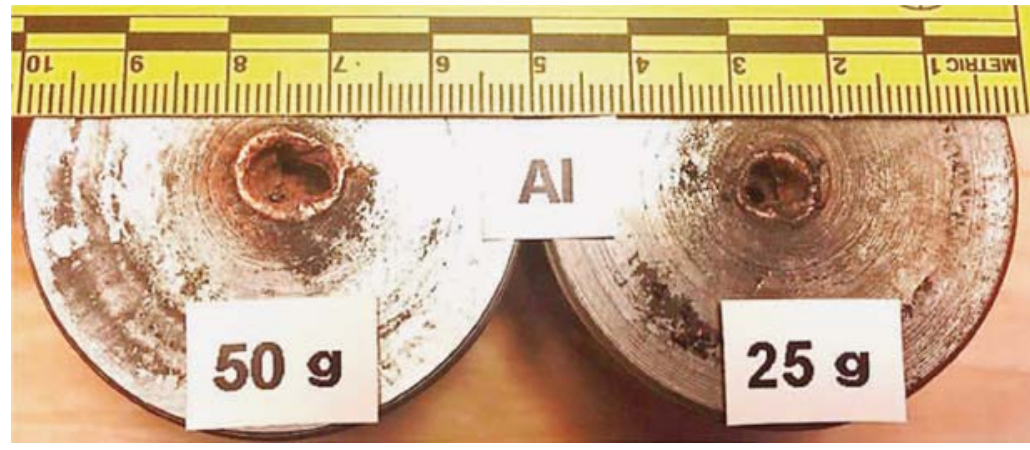

Figure 14: AnNmAl 50-25 g targets 
off and deformed the collar of the hole. The diameter was $9.2 \mathrm{~mm}$, the length was $31 \mathrm{~mm}$. In the case of binary explosives, classic nitroparaffin and ammonium-nitrate mixtures were used. Comparing these mixtures' effectiveness to RDX or PETN containing explosives, definite recession is perceptible, even so, jet formation exists. This test shows the correlation between this circumstance and the performance of all those materials which have detonation properties highly dependent on the diameter and confinement.. The large fraction prill containing AnNm detonation has failed this partial detonation, and this can be observed in Figure 12. The close up of the recovered liner and their comparisons can be seen in Figure 13. These early liner collapse deformation stages were firstly described by Birkhoff et al. (Birkhoff et al., 1948), and the initial liner collapses were validated also by experimental methods. (Scheid et al., 2014).

The AnNm and AnNmAl compositions were tested in $50 \mathrm{~g}$ and $25 \mathrm{~g}$ trials to examine the penetration decrease due to the lower charge weight. The results on the steel targets can be seen in Figure 14.

\section{Jet velocity testing experiments}

Besides the many factors which can modify a jet's penetration, one important value must also be mentioned. In the face of effectiveness, jet tip velocity gives a good estimation of how the shaped charge will perform. Needless to say that the highest velocity values can be achieved with precision manufactured pressed charges, loaded with RDX, HMX, HNS (Ester et al, 2006).

The principle of the procedure is similar to those in the case of detonation velocity (Vod) measurements (EN 13631-14 Determination of velocity of detonation. 2003) (Oertzen, 2013). The testing unit is equipped with a high resolution timer and it measures time between its probes and then calculates the speed of the detonation. High-end equipment (high speed imaging) (Shattuck, 2015) can give more complex results from jet particulation, (Tatake and Kharat, 1992) but a less sophisticated set-up can also handle the measurement. Break-wire methods were used. The calculation principle based on a time measuring the voltage-drop between electric probes. The probes in this case are a thin copper cable. The measurement setup can be observed in Figure 15, and it builds up from the following main parts:

- Explosive shaped charge;

- Measurement cable (optical and break wire) assembly with positioning pipe;

- Detonation time meter (resolution: $+/-0.1 \mu \mathrm{s}$ ).

The difficulties with this method are the following:

- In case of an asymmetrical jet forming, the jet tip does not cut the circuit wires, and this can result in "no measurement";

- If the break wires are not axial with the jet tip, it is possible that the lower velocity jet body or the end

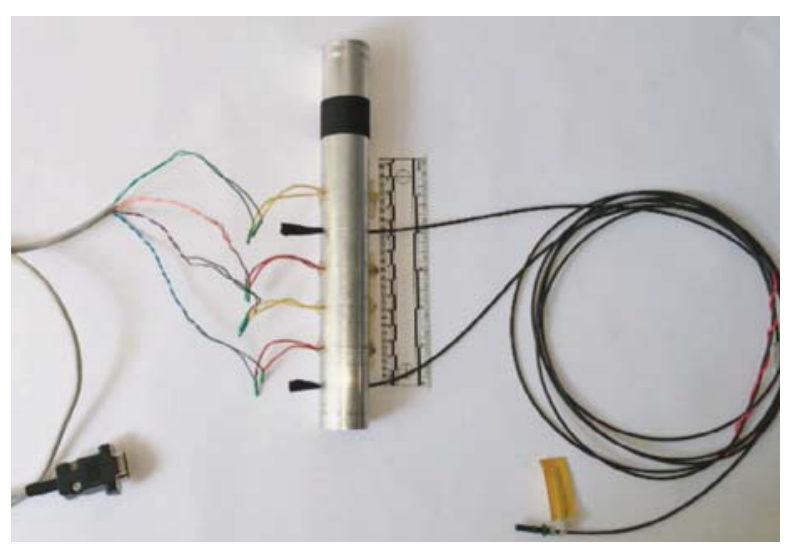

Figure 15: Jet velocity measurement setup with 2 different methods

slug will trigger the measurement. This can be verified if lower values appear;

- The optical and break wire method together are not reliable. The small copper particles ripped from the break-wire can easily destroy the optical wire well before it is triggered by the light itself;

- For the charges not manufactured with precision, the probes may need to be within the range of the optimal standoff distance (SoD) as the splattering of the jet occurs in larger SoD, more unpredictable test results will appear.

The measurements were not carried out for each case, rather than to have comparable results between the RDX and the binary explosives, and to verify that this method is also suitable for such measurements, results are shown in Table 2. As written in the preface, the "standard" charge was the RDX pressed charge, from a $40 \mathrm{~mm}$ grenade.

Table 2: Jet velocity first test results

\begin{tabular}{|l|c|c|c|c|c|}
\hline \multirow{2}{*}{ Probes } & \multicolumn{2}{|c|}{$\begin{array}{c}\text { RDX pressed } \\
\text { charge }\end{array}$} & \multirow{2}{*}{ Probes } & \multicolumn{2}{c|}{$\begin{array}{c}\text { Binary } \\
\text { explosive }\end{array}$} \\
\cline { 2 - 5 } \cline { 5 - 6 } & $\begin{array}{c}\text { Distance } \\
(\mathrm{mm})\end{array}$ & $\begin{array}{c}\text { Vod } \\
(\mathrm{m} / \mathrm{s})\end{array}$ & & $\begin{array}{c}\text { Distance } \\
(\mathrm{mm})\end{array}$ & $\begin{array}{c}\text { Vod } \\
(\mathrm{m} / \mathrm{s})\end{array}$ \\
\hline BW0-BW1* & 50 & 6493 & O1-O2** & 50 & 2475 \\
\hline BW0-BW2 & 75 & 6000 & O2-O3 & 50 & 2427 \\
\hline BW0-BW3 & 100 & 4149 & - & - & - \\
\hline
\end{tabular}

*: "BW" corresponds for break - wire method

**: "O" corresponds for optical method

To verify the 2 methods, a standard detonation velocity measuring test was conducted, in which both methods were done simultaneously. The highest deviances were $460 \mathrm{~m} / \mathrm{s}$. As the placing of both of the probe types are critical in the face of the result, this measuring method is also considered suitable for such jet velocity measurements. 


\section{Results}

The complete results can be found in Table 3, and Figure 16 in graph form. The performance row comes from the multiplication of the hole's collar diameter by its length, which serves as a ratio of penetration. Performance by weight results from the division of the mentioned ratio by the explosive weight. With this method, a sequence that correlates to the theoretical approach of the brisance of the used explosives can be set. The jet velocity measurements, both with the optical or break wire method, can be a good additional low-cost method for evaluating the performance of shaped charges. The results for the RDX pressed charge are within the values stated by the manufacturer. For the binary charges, further tests need to be performed, but the test results are in line with the difference shown in their penetration ability.

\section{Conclusions}

Figure 16 contains all the measured values organized in bar graphs. Each bar corresponds to one explosive, of which the lower blue part is the weight, and the upper is the performance by weight. Figure 16 confirms the theory that explosives with a higher detonation velocity (RDX, PETN) also have a higher energy content per mass. In the case of melt cast explosives, it shows that even they contain hexogen and the melting procedure has complex effects on penetration. In the case of binary explosives, the jet forms properly which correlates to a stable and higher detonation velocity, however, due to the lower density, the penetration stays at a lower level.

The motivation for undertaking this study was to compare different kinds of explosives concerning their detonation properties and to find the correlation between

Table 3: Complete test results

\begin{tabular}{|c|c|c|c|c|c|c|}
\hline Explosive & $\mathrm{m}(\mathrm{g})$ & $\mathrm{d}(\mathrm{mm})$ & $\frac{1}{(\mathrm{~mm})}$ & Performance & Performance by weight & Remark \\
\hline RDX & 14,3 & 7,3 & 51 & 372,3 & 26,03 & pressed \\
\hline Semtex PLHX 30 & 25 & 9,1 & 51,5 & 468,6 & 18,75 & $8 \% \mathrm{Al}$ content \\
\hline Semtex 1A & 25 & 9 & 46 & 414 & 16,56 & - \\
\hline Semtex 1A & 25 & 7 & 51,6 & 361,2 & 14,45 & waveshaper \\
\hline Comp-B_\#2 & 30,8 & 10 & 61,5 & 615 & 19,93 & cast \\
\hline Comp-B_\#6 & 46,1 & 11,2 & 72 & 810,7 & 17,59 & cast \\
\hline Comp-B_\#4 & 22,6 & 9,2 & 31 & 285,2 & 12,62 & cast \\
\hline Comp-B_\#3 & 25,1 & 9,4 & 32,3 & 303,6 & 12,1 & cast \\
\hline AnNmAl_50 & 50 & 6,1 & 34,7 & 211,6 & 4,23 & $2.5 \% \mathrm{Al}$ \\
\hline AnNmAl_25 & 25 & 5,7 & 24,7 & 142,7 & 5,71 & $2.5 \% \mathrm{Al}$ \\
\hline AnNm_50 & 50 & 5,6 & 30,5 & 170,8 & 3,42 & - \\
\hline AnNm_25 & 25 & 4,7 & 19,5 & 93,2 & 3,73 & - \\
\hline
\end{tabular}

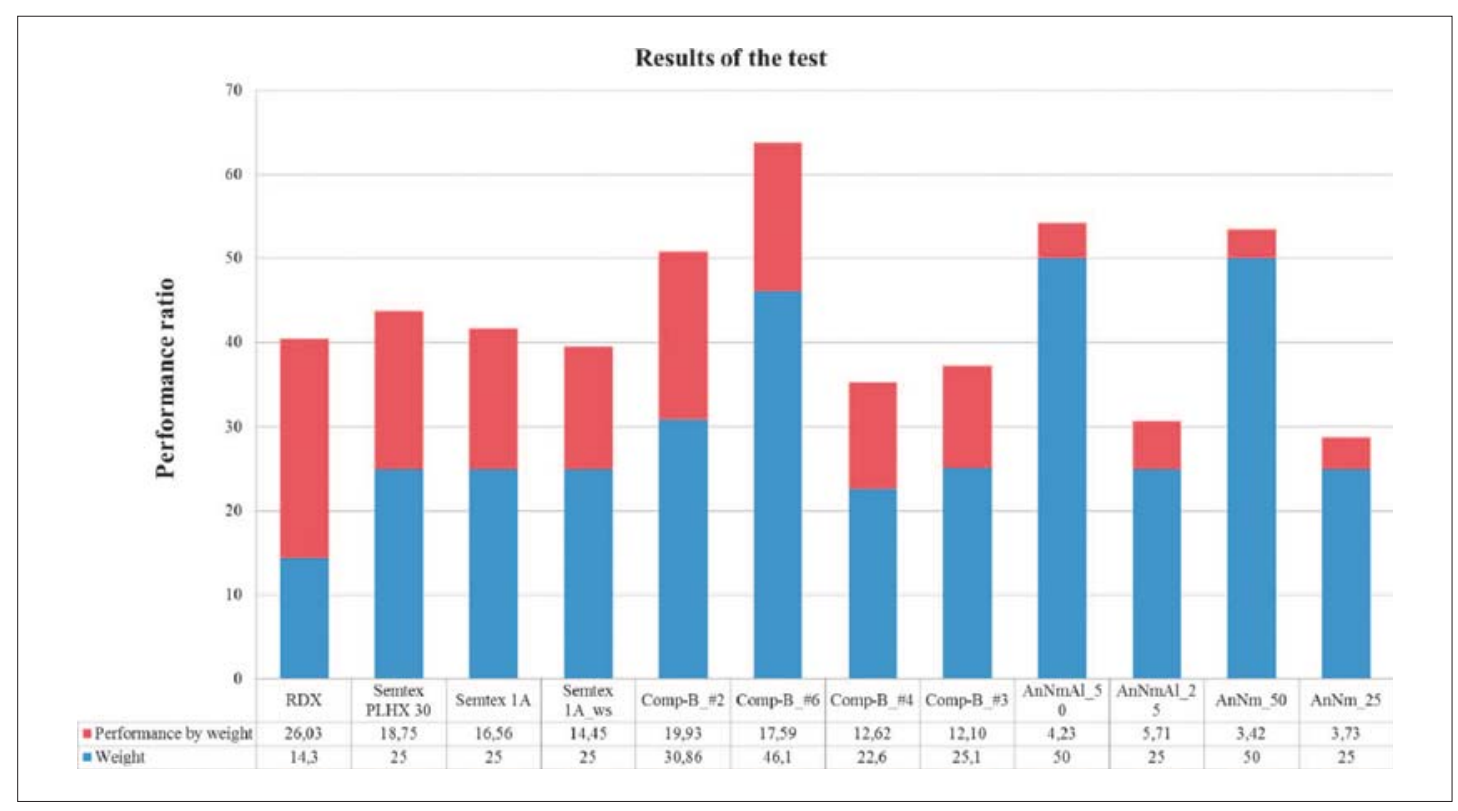

Figure 16: Compared results with explosive weight and performance 
their penetration abilities. In the case of developing new compositions or just verifying the adequate amount of energizers in the explosive, this practical method can be applied. From a theoretical point of view, their capabilities are predictable, however they are not quantified.

With this method, different explosive mixtures can be tested for shaped charges because both the jet formation and the proper detonation run up should be present. The composition has to detonate in small quantities and a relatively small diameter in order to create an appropriate jet.

From a practical point of view, it is a small-scale test that can be performed with grams instead of kilograms of materials. It can be accomplished in blasting chambers because specific instruments are not required. It is a suitable method for development, or other cases when reasonable comparability and repeatability are important factors.

\section{References}

Bakera, E.L., Phama, J., Madsena, T., Poulosa, W., Fuchsa, B.E. (2013): Shaped charge jet characterization and initiation test configuration for im threat testing. Procedia Engineering, 58, 58-67.

Birkhoff, G., MacDougall, D.P., Pugh, E.M., Taylor G.I. (1948): Explosives with lined cavities. Journal of Applied Physics, 19, 563-582.

Brown, J., Softley, I.D., Edwards, P. (1993): Experimental study of shaped charges with built-in asymmetries. Propellants Explosives Pyrotechnics, 18, 255-258.

Bohanek, V., Dobrilovic, M., Skrlec, V. (2012): Jet velocity of linear shaped charges. Rudarsko-geološko-naftni zbornik (The Mining-Geological-Petroleum Engineering Bulletin), 25, 1, 73-80.

Bohanek, V., Dobrilovic, M., Skrlec, V. (2014): The efficiency of linear shaped charges. Tehnicki Vjesnik 21, 3, 525-531.
Kamarudin, K.H., Zaidi, A.M.A., Abdullah, S., Koslan, M.F.S. (2016): Establishment of shaped charge optimum parameters for small scale hydrodynamic penetration. Modern Applied Science, 10, 1, 82-92.

Oertzen, A.V. (2013): Demonstration of proficiency by roundrobin tests among explosives Notified Bodies. In: Rennert J. (ed.): Proceedings of the 7th World Conference on Explosives and Blasting. Moscow. 78-81.

Scheid, E., Burleigh, T.D., Deshpande, N.U., Murphy, M. (2014): Shaped charge liner early collapse experiment execution and validation. Propellants Explosives Pyrotechnics, 39. 739-748.

Shattuck, M.S. (2015): Determination Of Detonation Velocity Of Explosive Compounds Using Optical Techniques. New Mexico Institute of Mining and Technology, Department of Mechanical Engineering, Explosives Engineering. 11-17.

Tatake, S.G., Kharat, D.K. (1992): Flash X-Ray: a diagnostic tool for shaped charge studies. Defence Science Journal, $42,4,259-264$.

Walters, W.P., Zukas, J.A. (1989): Fundamentals of shaped charges. Wiley-Interscience, New York, 398 p.

Ester, Z., Dobrilović, M., Janković, B., Tomičić, Z., Odak, M. (2006): Jet velocity and the effects of the shaped charge perforator for use in the oil and gas well. In: Ottis J., Krupka M. (eds.): Proceedings of the New Trends in Research of Energetic Materials 9th International Seminar. Pardubice. 581-586.

\section{Reports:}

EN 13631-14 (2003): Explosives for Civil Uses. High Explosives, Part 14. Determination of velocity of detonation. European committee for standardization.

TM 9-1300-214 Military Explosives. (1984): Department Of Army Technical Manual. Delta Press. 119 p.

\section{SAŽETAK}

\section{Određivanje učinkovitosti perforatora malih dimenzija na čeličnim metama}

U radu su prikazana istraživanja prilikom testiranja perforatora malih dimenzija. Uzorci su izrađeni od kompozita-B, semteksa i prešanoga RDX-a, binarnih eksploziva i emulzijskoga eksploziva. S obzirom na to da se obloga perforatora nije mijenjala, izabran je penetracijski test u mete izrađene od mekanoga čelika, a kao metoda za usporedbu i kvantificiranje učinkovitosti perforatora. Postav meta za mjerenje učinka standardizirano je izrađen od čeličnih diskova. Za vrijeme testiranja opaženo je kako test može poslužiti kao praktičan razvojni alat za određivanje optimalne mješavine binarnih eksploziva. S obzirom na to da se u literaturi mogu naći uglavnom teorijska razmatranja učinkovitosti perforatora, ovo je primjer razvoja jednostavne ispitne metode prilagođene primjeni na terenu.

\section{Ključne riječi:}

lijevani eksploziv, perforator, penetracijski test, binarni eksplozivi

\section{Author contribution}

Lorand Kugyela (explosive engineer, environmental engineer) initialized the principal idea and carried out all the tests, as a part of PhD thesis research regarding new explosive mixtures. 